\title{
"Um médico em forma de revista": Aspectos constitutivos da revista adventista Vida e Saúde (1939-2019)
}

\author{
Karina Kosicki Bellotti*
}

\section{Resumo}

Abordamos a relação entre religião, saúde e mídia nos 80 anos da revista publicada pela Igreja Adventista do Sétimo Dia, Vida e Saúde, de cujos aspectos gerais traçamos um panorama geral, de 1939 a 2019. Discutiremos o levantamento quantitativo das edições da revista e a relação da mensagem adventista de saúde com sua filosofia editorial, escolha de anunciantes, formas de distribuição, capas, slogans, seções e artigos. Observamos duas periodizações: a primeira (anos 1930 a 1960) foi uma fase americanizada, com abordagem higienista de saúde; a segunda fase (1970s-) dialoga com as demandas brasileiras. O tema predominante da publicação é a saúde física conseguida por meio do uso dos oito remédios naturais defendidos pela igreja.

Palavras-chave: Igreja Adventista do Sétimo Dia; saúde; mídia impressa; revista; corpo.

\section{"A physician in magazine form": Constitutive aspects of the Adventist magazine Vida e Saúde [Life and Health] (1939-2019)}

\section{Abstract}

One approaches the relation between religion, health and media in the 80 years of the review published by the Seventh Day Adventist Church, Vida e Saúde [Life and Health], whose general aspects one analyzed from 1939 to 2019. One discusses both the quantitative study of the editions of the review and the relation between the Adventist health message with the magazine's editorial philosophy, choice of sponsors, forms of distribution, covers, slogans, sections and articles. One observes two periods for the review: the first one (1930s-1960s) was the Americanized phase, with hygienist approach of health; the second (1970s-) has dialogued with the Brazilian demands. The main theme throughout the 80 years of magazine has been the physical health achieved using the eight natural remedies defended by the church.

Key words: Seventh Day Adventist Church; health; printed media; magazine; body.

* Doutora e mestre em História Cultural pela Unicamp; Professora do Departamento de História da Universidade Federal do Paraná. karinakbellotti@gmail.com 


\section{"Un medico en forma de revista": Aspectos constitutivos de la revista adventista Vida e Saúde [Vida y Salud] (1939- 2019)}

\section{Resumen}

Nos acercamos a la relación entre religión, salud y médios de comunicación en los 80 años de la revista publicada por la Iglesia Adventista del Séptimo Día, Vida e Saúde, cujos aspectos generales hemos esbozado de 1939 a 2019. Discutiremos la encuesta cuantitativa de las ediciones de la revista y la relación del mensaje adventista de salud con la filosofia editorial, a elección de anunciantes, formas de distribuición, portadas, slogans, secciones y artículos. Observamos dos períodos: el primeiro (de 1930 a 1960) fue uma fase americanizada, com um enfoque higienista de la salud; la segunda fase (1970-) dialoga com las demandas brasileñas. El tema predominante de la publicación es la salud física lograda mediante el uso de los ocho remédios naturales recomendados por la iglesia.

Palabras-clave: Iglesia Adventista del Séptimo Día; salud; médios impresos; revista; cuerpo.

\section{Introdução}

"Um médico em forma de revista" - foi assim que a leitora Lílian Regina de Freitas descreveu a revista Vida e Saúde, em carta publicada em janeiro de 1999 (CORREIO, 1999, p. 33). Conhecida por seus conselhos de saúde, a revista completou 80 anos de circulação mensal ininterrupta em 2019, sendo editada pela Casa Publicadora Brasileira, pertencente à editora da Igreja Adventista do Sétimo Dia no Brasil (IASD). O tema deste artigo é a relação entre religião, saúde e mídia, analisada em amostragem dos 80 anos da revista Vida e Saúde. Apesar de sua longevidade, a revista foi pouco estudada na academia, por isso, em nossa investigação traçamos um panorama dos seus aspectos gerais para subsidiar futuras pesquisas, tendo em vista o crescimento da área de estudos sobre religião e saúde nos últimos anos ${ }^{1}$.

A revista Vida e Saúde começou a ser publicada em janeiro de $1939^{2}$, no contexto do Estado Novo brasileiro (1937-1945), que adotou políticas

\footnotetext{
Este artigo traz resultados da pesquisa de pós doutorado conduzida no Departamento de Sociologia da Universidade Federal de São Carlos (UFSCar) entre fevereiro de 2019 e janeiro de 2020. Meus agradecimentos ao Centro White, da Universidade Adventista de São Paulo, campus Engenheiro Coelho, pela permissão para pesquisar nos seus acervos.

2 Uma primeira versão da revista, denominada Saúde e Vida, foi lançada em 1914, mas durou poucos meses e saiu de edição no mesmo ano. Não há muitas informações sobre essa primeira versão - não encontramos exemplares para pesquisar, nem fontes que explicassem as possíveis razões para a descontinuidade da revista em tão pouco tempo.
} 
higienistas e eugênicas para a população. O título da revista Vida e Saúde é o mesmo da congênere norte-americana, Life and Health, publicada pela editora adventista Review and Herald Publisher desde 1904. A revista publicou até os anos 1970 muitos artigos advindos da versão americana, além de ter emulado alguns dos layouts de suas capas nas primeiras décadas de sua existência.

A Igreja Adventista do Sétimo Dia é uma denominação cristã de origem estadunidense fundada em 1863. Ela teve como uma de suas principais lideranças a escritora Ellen Gould White, que durante boa parte de sua vida afirmou ter visões proféticas, divulgadas pelos jornais, revistas e livros da denominação, e que até os dias atuais são referência teológica para a igreja. Dentre estas visões esteve a mensagem de saúde, que se tornou uma das características marcantes da igreja, juntamente com a guarda do sábado como dia santo (LAND, 2005). Por influência do movimento de reforma da saúde em curso desde os anos 1830 nos EUA, os adventistas defendem a adoção de um estilo de vida saudável como forma de prevenção de doenças, incorporando os oito "remédios naturais": "Ar puro, luz solar, abstinência, repouso, exercício, regime conveniente, uso de água e confiança no poder divino - eis os verdadeiros remédios." (WHITE, 2013, p.80).

A IASD iniciou suas atividades no Brasil no final do século XIX, por meio da distribuição de literatura sabatista entre comunidades de imigrantes alemães no sul do país (BORGES, 2000). Vale ressaltar a importância da mídia impressa para a denominação. Desde 1900 a Casa Publicadora Brasileira publica literatura adventista a fim de despertar o interesse dos brasileiros para a igreja, sendo a mensagem de saúde uma das principais aliadas desta estratégia. Após a publicação de livros norte-americanos sobre saúde traduzidos para o português, a denominação lançou Vida e Saúde.

O periódico teve inicialmente 24 páginas em preto e branco, incluindo capa e quarta capa em quatro cores, aumentando esse número ao longo das décadas até chegar às atuais 52 páginas coloridas, a partir dos anos 2000. A coleta de exemplares teve o objetivo de criar uma amostragem que abrangesse ao menos um ano completo a cada cinco anos, ou que incluísse o índice anual de matérias na edição de dezembro, uma prática mais corrente a partir dos anos 1960. Seguindo a metodologia de análise da historiadora Tania de Luca (2011, pp 111-154), buscamos analisar como os elementos constituintes da revista - textos e imagens - dialogam entre si e como criam sentidos para seus leitores no que se refere à saúde. Além disso, estabelecemos uma classificação dos principais temas recorrentes na revista, a fim de observar 
se houve mudança de orientação na filosofia editorial e se houve mudanças na escolha de temas ao longo dos anos. Nas últimas décadas, os editores da revista têm defendido que saúde física, mental e espiritual possuem igual importância, formando o tripé da concepção de boa saúde. Porém, o principal fator que nos impeliu a fazer esse levantamento foi a presença maciça, durante a análise das edições de 2018 e 2019, de matérias sobre saúde física e cuidados com o corpo, em quantidade muito maior em relação a temas de saúde mental, emocional e espiritual.

Observamos que a saúde física foi o principal tema de artigos e seções da revista desde o seu início, conforme levantamento quantitativo de 1939 a 2018. A despeito de estudos temáticos publicados anteriormente, três sobre a relação da publicação com questões de gênero (DALBEN; SOARES, 2009, pp. 239-250; SOARES; LEOPOLDO E SILVA; CAMPOS, 2014, pp. $142-$ 160; BACH, 2017) e um sobre longevidade (LEMOS, 2015), tais aspectos mostraram-se minoritários em relação aos temas da saúde física. Contudo, reconhecemos a importância destes estudos temáticos aprofundados, que abriram caminho para a pesquisa da revista. Dessa forma, a análise de seus elementos constitutivos e de seu desenvolvimento ao longo do recorte de 80 anos intenta oferecer uma referência sobre o que é possível encontrar no periódico, e como determinados elementos podem ser compreendidos à luz da mensagem e da atuação de IASD no ramo da saúde.

No campo dos estudos sobre religião e saúde, têm se destacado pesquisas acerca da influência de crenças e práticas religiosas, tanto de instituições como de indivíduos, sobre os tratamentos de saúde, ao passo que a área de saúde tem incorporado conceituações de espiritualidade (KOENIG, 2012; TONIOL, 2015, 2017; STROPPA; MOREIRA-ALMEIDA, 2008, pp. 427-443). Este artigo lida com uma relação ainda pouco explorada - religião, saúde e mídia, que ainda possui poucas publicações (BADARACCO, 2007; GRIFFITH, 2004, além das supracitadas sobre Vida e Saúde), apesar de oferecer um campo de exploração fértil no caso de grupos religiosos que oferecem serviços de saúde pelos meios de comunicação, entrando em concorrência com outros grupos religiosos e/ou com a própria medicina. $\mathrm{O}$ caso adventista é instigante pelo fato de sua mensagem de saúde e de suas mídias impressas formarem a identidade da igreja desde o início, alinhando-se ao discurso médico e científico, sem assumir postura proselitista.

Apontamos duas grandes tendências predominantes no desenvolvimento da revista: uma primeira fase, dos anos 1930 a 1960, em que 
a revista é americanizada na sua estética (capas, ilustrações e fotos internas) e nas matérias escritas majoritariamente por autores americanos (médicos e enfermeiras, com ou sem filiação adventistas), e de orientação higienista e eugenista, com textos reproduzidos das cartilhas de higiene e saúde do Serviço Nacional de Educação Sanitária (SNES) e do Serviço de Propaganda e Educação Sanitária de São Paulo (SPES-SP) durante e após o Estado Novo. A segunda fase ocorre a partir dos anos 1970, com uma transformação que se consolida nos anos 1980, em que a revista produz suas próprias capas, ao invés de tirar imagens de bancos de fotografias norte-americanos, e suas matérias são escritas por mais autores brasileiros - jornalistas, médicos e outros profissionais da saúde - dialogando com problemas de saúde do nosso país. Analisamos o histórico da revista a partir de seis aspectos: a filosofia editorial, os anunciantes e as formas de distribuição, as capas, os slogans, as seções e os artigos, que compõem as seis partes deste artigo.

\section{Filosofia Editorial e Público Alvo}

A revista Vida e Saúde é uma "revista de consumo segmentada por interesse", isto é, uma revista voltada para o público em geral, abordando assuntos de saúde (ALI, 2009, p. 20). Segundo Fátima Ali (2009, pp. 38-39), "os principais componentes de um conceito editorial são: a missão, o título e a fórmula", isto é, as revistas costumam ter um perfil do tipo de leitor/a almejado, uma filosofia editorial e uma fórmula editorial que estabeleça a combinação entre seções fixas, colunas e matérias, além de um título que traduza seus principais objetivos. Todos esses elementos são encontrados em Vida e Saúde. Realizamos uma comparação entre os editoriais da primeira edição, de 1939 e das edições comemorativas de 2008, dos 70 anos da revista, para observar qual a filosofia editorial defendida nesses momentos históricos.

No início, o seu público-alvo era amplo, preferencialmente nãoadventista, almejando duas instâncias principais - a família nuclear e a classe médica. Atualmente, o público-alvo continua amplo, privilegiando o público adulto. Com o lema "Revista mensal ilustrada sobre saúde e higiene", a primeira edição de Vida e Saúde, de janeiro de 1939, trouxe o editorial "Nossa Programa" do redator-chefe Luiz Waldvogel, explicando os objetivos da revista em um contexto de intenso crescimento da ação política da medicina e da higiene no Brasil. 
O discurso da revista nos seus primeiros anos alinhou-se com a política higienista e o discurso eugênico defendidos pela classe médica e pelo governo Vargas. Lemos no primeiro editorial de Vida e Saúde:

O Brasil despertou. Novas auras o bafejam e revigoram. E especialmente grato nos é ver que esse despertar se acentua no domínio das ciências, e sobretudo no da medicina e higiene. (...) Há necessidade de ampliarmos indefinidamente nosso conceito de vida higiênica, da vida útil, gozada, na verdadeira acepção do termo. Por isso mesmo nossos médicos, mais do que nunca, se preocupam com os problemas relativos à nossa alimentação, à pediatria, à cultura física, à melhoria eugênica da raça, enfim (WALDVOGEL, 1939a, p.3).

Tratou-se de um alinhamento estratégico - ao defender os princípios higiênicos do poder dominante, e da classe médica que possuía autoridade no campo da saúde, os adventistas, uma minoria religiosa, estariam em "boa companhia", sem apresentar contestações nem desafios a quem pudesse lhe ameaçar. Isso se confirma nos exemplares da revista até mesmo após o período do Estado Novo. Mas também segue um ideal presente desde as primeiras revistas de saúde adventistas do século XIX e nas mensagens de saúde divulgadas por Ellen G. White em seus livros. Em "A Ciência do Bom Viver" (WHITE, 2013), a perspectiva higienista de prevenção e saúde perpassa todos os conselhos e os "remédios naturais" eram considerados elementos conferidos por Deus para que os seres humanos vivessem boa saúde e alegria, modelando seu corpo para o ideal deixado por Jesus Cristo.

Em Vida e Saúde, nessa primeira fase, a maioria dos remédios naturais aparecem com frequência, em separado ou em combinações, com fins preventivos, medicinais e civilizatórios. A água pura devia ser ingerida e usada em abundância para banhos e tratamentos hidroterápicos, em uma época em que nem toda a população tinha acesso à água tratada (nem hoje ainda possui); o ar puro, a ser respirado nas caminhadas ao ar livre e a purificar ambientes antes sujeitos à insalubridade (em especial na área rural e nas periferias dos centros urbanos); a luz solar, a ser aproveitada nas caminhadas, na helioterapia e nos ambientes domésticos; a atividade ou exercício físico, para tonificar os músculos, estimular a respiração e a transpiração; o repouso para recarregar as energias; a alimentação saudável, com todos os nutrientes necessários para o funcionamento perfeito do corpo - de preferência, sem alimentos cárneos, que colocariam em risco da saúde de qualquer pessoa (em um período de escassez de leite, derivados e carnes esterilizados). Predomina 
nessa fase uma noção de vida natural, advinda da obra de Ellen G. White (ainda que não explicitamente citada), que se contrapunha à vida moderna, considerada fonte de degradação da saúde física, mental e espiritual. Por isso, o domínio próprio, sétimo remédio, abarcava desde o autocontrole na escolha de alimentos e na quantidade ingerida, até a abstinência de álcool, fumo e substâncias narcotizantes e estimulantes, como chá, café, temperos fortes. Já a confiança em Deus, oitavo remédio natural, é muito presente na obra de Ellen G. White, mas não aparece tanto na revista até os anos 1970, quando uma seção sobre espiritualidade ("O Melhor da Vida") se tornará fixa até os dias atuais ("Vida Plena").

O primeiro editorial afirmou que a revista tinha por objetivo ser científica, "sem eruditismo científico e exibição de frases feitas (...)" (WALDVOGEL, 1939a, p.3). Não há menções a nenhum princípio religioso, mas na matéria seguinte ao editorial, seu autor, o médico adventista Frederico Rossiter (1939, pp. 4-5), referiu-se ao corpo humano como uma perfeita obra do "Creador". A escassez de referências religiosas ou espirituais pode ser lida como uma estratégia para evitar a rejeição deste grande público a que a revista almejava - afinal, a família nuclear interpelada no editorial podia ser qualquer família, com ou sem filiação religiosa - ou provavelmente católica. Isso também explica a menção genérica a Deus como Criador, e aos evangelistas como "São Lucas" ou "São Mateus", ao citar os parcos trechos bíblicos encontrados nos exemplares até a década de 1960.

A menção ao fato de a publicação ser de uma instituição adventista era raríssima. Um exemplo disso está na lista de distribuidores que a revista publicou entre os meses de janeiro a março de 1939 - na nota "Nossas Agências" (1939a, p.23) consta uma lista de distribuidores identificados como adventistas - "Sociedade Nordeste Brasileira de Publicações Adventistas" (Pernambuco), "Sociedade Baiana de Publicações Adventistas" (Bahia), dentre outras, de norte a sul do país. Isso durou somente três meses, pois a partir da edição de abril de 1939 (NOSSAS AGÊNCIAS, 1939b, p.22), qualquer menção ao adventismo desaparece da publicação. Além disso, raramente vemos textos de Ellen G. White publicados na revista, e mesmo assim, ela é mencionada (quando mencionada) como "escritora", sem nenhuma associação ao adventismo. Seus livros são divulgados nas propagandas na quarta capa da revista, mas seu nome não é mencionado como autora. Atualmente, a revista incorpora a espiritualidade como parte de seu discurso sobre saúde, mas continua evitando o proselitismo, alinhando-se a uma abordagem científica 
que corrobora seus preceitos de bom viver e os oito remédios naturais (SCHUNEMANN, 2008).

A preocupação da revista em ser útil na instrução sobre o corpo e a saúde também é visível não somente pela adoção da linguagem acessível, mas também por se alinhar ao princípio da educação sanitária em curso no Estado Novo $^{3}$ - levar ao povo as informações necessárias para o cuidado com o corpo, a prevenção de doenças por meio de hábitos de higiene e de boa alimentação, a adesão às vacinas, dentre outras medidas:

(...) havemos de levar ao povo a leitura que os inicie suavemente nos mistérios do nosso corpo, nas leis que regem o organismo, nas condições ideais da boa saúde. Ao vosso lar, prezado leitor, levaremos ensinamentos que hão de tornar mais suportáveis as exigências crescentes que a vida impõe a todos os membros da família (WALDVOGEL, 1939a, p.3).

Chama atenção o fato de este editorial não ser reproduzido nas edições comemorativas da revista em 2008 dos 70 anos de Vida e Saúde. Nelas é reproduzido um resumo da sua filosofia editorial, acrescentando elementos mais visíveis nas matérias da revista a partir dos anos 1980, com o aumento da preocupação ecológica como parte da preservação da saúde humana:

Filosofia Editorial de Vida e Saúde

1. Promover a saúde, ensinando o leitor a prevenir doenças através dos oito remédios naturais: alimentação saudável, exercício físico, água, ar puro, luz solar, abstinência de coisas nocivas (exemplo: ódio, gula, fumo, bebidas alcoólicas e outras drogas), repouso e confiança no poder divino;

2. Popularizar o estilo de vida saudável;

3. Divulgar a filosofia bíblica da saúde, que valoriza o corpo do homem e da mulher como um verdadeiro tesouro presente de Deus;

4. Alertar a sociedade quanto aos riscos da destruição do Planeta, e promover atitudes que protejam as pessoas, os animais, os rios, as fontes de água, o ar, as florestas (LEMOS, 2008b, p. 4)

3 Os nomes de muitos/as autores/as estrangeiros de artigos e seções na revista até os anos 1970 foi "abrasileirado", o que podemos interpretar como influência da política nacionalista do Estado Novo - assim, Dr. Jean Nussbaum virou Dr. João Nussbaum; Dr. Percy T. Magan tornou-se Dr. Perci T. Magão e Dr. Charles T. Batten, Dr. Carlos T. Batten. Após os anos 1970 o abrasileiramento de nomes de autores estrangeiros diminuiu até terminar, nos anos 1980. 
Os elementos do primeiro item não são destacados no editorial "Nosso Programa", mas aparecem na revista nos artigos de autores adventistas e de médicos higienistas, que abordam os remédios naturais. Esse item elenca dentre os "elementos de coisas nocivas", além das substâncias entorpecentes, o sentimento negativo (ódio) e o descontrole alimentar (gula), indicando a importância que a saúde emocional adquire na revista desde os anos 1970. O segundo item é uma decorrência do primeiro item, pois a prática dos oito remédios levaria a um estilo de vida saudável a ser divulgado pela revista. Já o terceiro item mostra a disposição dos editores em incluir os corpos das mulheres, e não somente "o homem" como modelo de corpo - modelo este que predomina em boa parte da história da revista, como representante da humanidade e exemplo de corpo humano. Essa linguagem mais inclusiva é tendência na revista a partir dos anos 2000.

O quarto item é uma preocupação com o consumo sustentável. O vegetarianismo estrito favoreceria o meio ambiente, e não somente a saúde humana, ao não estimular práticas predatórias, crueldade com os animais, alto consumo de água e de recursos naturais que se vê na pecuária, por exemplo. Ainda que o alerta para a crueldade com os animais produzida pela dieta onívora aparecesse desde o início do adventismo (WHITE, 2013), ele é ressignificado a partir de um novo contexto, em que as formas atuais de obtenção industrial de leite, carne e ovos envolvem a mecanização intensiva que confina os animais, sujeitando-os à injeção de hormônios e antibióticos e limitam seu ciclo natural de vida.

O que é reproduzido de 1939 nas edições de 2008 são trechos de artigos, como a matéria sobre o feijão-soja, a importância dos exercícios físicos para combater o sedentarismo, e o combate à obesidade, como forma de mostrar que a revista sempre esteve na vanguarda dos cuidados com a saúde. Porém, o primeiro editorial não é lembrado - e apostamos que um dos principais motivos seja seu teor higienista e eugênico. Termos como degeneração ou melhoramento da raça estavam presentes nos escritos de Ellen G. White e em Vida e Saúde, quando o pensamento racializante encontra acolhida na academia e em parte da opinião pública na Europa, nos Estados Unidos e na América Latina (DIWAN, 2007). Porém, não encontramos referências a essas ideias nos periódicos adventistas das últimas décadas.

O perfil dos editores alterou-se ao longo dos anos, fruto da profissionalização da área do jornalismo no Brasil a partir da segunda metade do século XX. Se desde os anos 1970 os editores de Vida e Saúde 
possuíam formação em jornalismo, ou atuação profissional da área, nos anos 1930 não havia essa possibilidade. Muitos dos editores eram funcionários da Casa Publicadora Brasileira e dedicavam-se à edição de outras revistas, como a Revista Adventista, e de livros - a exemplo de Luiz Waldvogel. Um aspecto comum a todos os editores que tiveram localizadas suas informações é a sua formação teológica - com exceção de dois médicos adventistas que atuaram nos anos 1940 e 1950 - Galdino Nunes Vieira e Antonio A. Miranda. Assim, o alinhamento teológico da revista era uma preocupação não só dos editores, mas da própria IASD, que coordena todas as ações de suas empresas. A equipe editorial da revista, durante décadas, sempre foi muito enxuta, contando com um editor ou redator-chefe, um editor ou redator associado, consultores médicos e a partir dos anos 1970, uma equipe de Arte e diagramação. Atualmente a revista conta com uma série de colaboradores que são jornalistas, profissionais da saúde e de especialidades diversas - em sua maioria, adventistas.

\section{Anunciantes e distribuição}

Nos primeiros anos da revista, o anúncio de produtos alimentícios mirou as mulheres como público-alvo, como a Maisena Duryan e os doces enlatados Peixe. Além disso, o periódico anunciava literatura da CPB para todos os públicos. O argumento no primeiro editorial de que a revista não se "locupleta com pingues remunerações monetárias" (WALDVOGEL, 1939 a, p.3) pode ser lido como a recusa em receber dinheiro para exaltar produtos, tratamentos e medicamentos. Mas a revista não rejeitou publicidade. Durante muito tempo a Vida e Saúde possuiu anunciantes que se adequavam ao seu perfil editorial, como empresas de alimentos naturais e vegetarianos, por exemplo da adventista Superbom, além de clínicas de saúde e hospitais adventistas, como a Clínica São Roque, Hospital Silvestre (RJ) e CEVISA (SP). A presença de diversos anunciantes nas décadas de 1980 a 2000 não pareceu restringir as temáticas escolhidas nem a abordagem adotada nas matérias.

Mas desde meados dos anos 2010, a revista tem anunciado somente os livros publicados pela própria Casa Publicadora Brasileira. No vídeo "80 anos da mais antiga revista de saúde do Brasil", disponível no site de Vida e Saúde, o atual editor Michelson Borges (2019) afirma: "como não dependemos de verba publicitária, não temos compromisso com a indústria e interesses comerciais, ou seja, temos total liberdade editorial para tratar dos temas que 
escolhemos para cada edição”. Segundo Marília Scalzo (2014), atualmente muitas revistas comerciais têm procurado se manter à base de assinaturas, a fim de preservar esta liberdade editorial e manter longevidade, frente ao avanço da internet.

O fato de Vida e Saúde manter-se por meio das assinaturas e da colportagem - venda de porta em porta feita por membros da igreja - suscita uma reflexão sobre a relação entre a longevidade da revista e a limitação de sua tiragem. Sua longevidade pode ser atribuída à distribuição pelos colportores para um público interessado em saúde, o que lhes garante uma renda que ajuda a prover sustento e a pagar mensalidades em instituições de ensino superior adventista, no caso de estudantes. Tal renda seria suprimida caso a revista fosse vendida em banca. Isso pode repercutir numa tiragem limitada em relação a outras revistas de saúde, ao menos se verificarmos sua tiragem a partir dos anos 1990. Desde fevereiro de 2019 a revista não publica mais sua tiragem - até então ela estava em 60 mil exemplares ${ }^{4}$. A revista Vida e Saúde chegou a ser vendida em bancas no início de 2000, numa iniciativa que durou menos que seis meses, e não se repetiu mais.

Ainda assim, o periódico se tornou um pilar das publicações adventistas de uma maneira que não ocorre nem nos Estados Unidos, onde sua revista de saúde agora só existe no formato digital (Vibrant Life), seguindo a tendência de maior acesso da população às mídias digitais. No Brasil, a IASD e a CPB investem até hoje em campanhas para colportagem, ressaltando a importância

4 Em dezembro de 1939, Luiz Waldvogel comemorava o fato de a revista ter alcançado 18 mil assinaturas (WALDVOGEL, 1939b, p. 3), enquanto o Cruzeiro, a revista de variedades de maior vendagem na época, estreou com 35 mil exemplares vendidos em 1928 (ALI, 2009, p. 354). Houve flutuações significativas de tiragem entre as décadas de 1990 e 2000, períodos de crises econômicas, em que gastos com publicações são considerados supérfluos. A revista publicou sua tiragem somente a partir dos anos 1990. Em 1990, a revista teve tiragem média de 100 a 110 mil exemplares; em 1999, de 55 mil (em janeiro) a 35 mil (dezembro); em 2000, de 45 mil, crescendo nos anos seguintes. Em 2005 a tiragem começou a ser auditada pela empresa PricewaterhouseCoopers, variando de 73 a 85 mil exemplares; em 2008, foi de 319 mil a edição comemorativa de 70 anos, mantendo-se depois entre 75 e 76 mil exemplares; entre 2017 e abril de 2019, a tiragem foi de 60 mil exemplares, sendo que após esse mês, esse dado deixou de ser publicado. A revista de saúde campeã em vendas em bancas e assinaturas é Saúde! é Vital, da editora Abril, cuja circulação líquida é de 97.123 exemplares, sendo 88.393 por assinatura e 8.184 por venda avulsa (MARCAS E PLATAFORMAS, 2019), segundo levantamento feito pelo Instituto Verificador de Comunicação (IVC) em julho de 2019. 
que os meios impressos distribuídos de maneira personalizada possuem na evangelização e na distribuição de mensagens que trazem benefícios para o público em geral, reatualizando a tradição da colportagem em épocas de mídias digitais, fake news e comunicações aparentemente "desencarnadas" na ciberesfera.

\section{Capas}

A capa é um elemento importante de qualquer revista no século $\mathrm{XX}$, por isso, observaremos o tipo de comunicação visual que Vida e Saúde estabeleceu com seu público, e quais valores adventistas foram transmitidos por meio delas. Infelizmente, por conta do espaço, dedicaremos a uma análise abreviada das capas, que merecem um texto à parte. Alguns temas predominaram nas capas da revista na primeira fase, de 1939 até 1970, com ilustrações e fotografias (fig.1): cenários da natureza, com ou sem pessoas em meio a eles, e cenários urbanos com jardins (terceira e quarta capas da fig.1, setembro de 1956 e maio de 1960), além de flores e frutas; crianças em especial bebês ou crianças pequenas (segunda capa da fig.1, de abril de 1950), com ou sem a figura da mãe; jovens e, em menor número, famílias, casais jovens (primeira capa da fig.1, de outubro de 1939). Era uma constante a tendência de seguir o imaginário natural e campestre, pregado pelo adventismo de Ellen G. White, que defendia a proximidade do ser humano com a natureza como promessa de regeneração da saúde, frente à crescente modernidade urbana (WHITE, 2013). As pessoas retratadas eram sempre brancas, jovens, magras, seja nas capas tiradas de bancos de imagens norteamericanos, seja em algumas capas produzidas no Brasil.

As capas não tinham entre 1939 e 1970 relação alguma com matérias específicas da revista, e possuíam pouca ou nenhuma chamada. Elas vendiam um ideal de saúde, de forma física, de lar e família ligados à representação estética norte-americana do período. Esse é um grande referencial para os adventistas brasileiros, que ainda traduziam obras de autores americanos, e associavam sua mensagem de saúde às imagens de saúde e vivacidade produzidas pelo adventismo americano. No Brasil, a partir dos anos 1950, as capas passaram a ser comentadas, tal como ocorria na Life and Health, em uma pequena nota na terceira página da revista, junto ao expediente da revista. As fotos passaram a ser tiradas por Bernardo E. Schuenemann, gerente da revista, ou enviadas por colaboradores, ou retiradas de bancos de imagens. 
Figura 1 - da esquerda para a direita - capas de Vida e Saúde de outubro de 1939 (sem identificação de fonte); abril de 1950 (sem identificação); setembro de 1956 (foto da praça Moscoso, em Vitória-ES); maio de 1960 (foto tirada pelo pastor adventista Mário Rasi, sem localização).
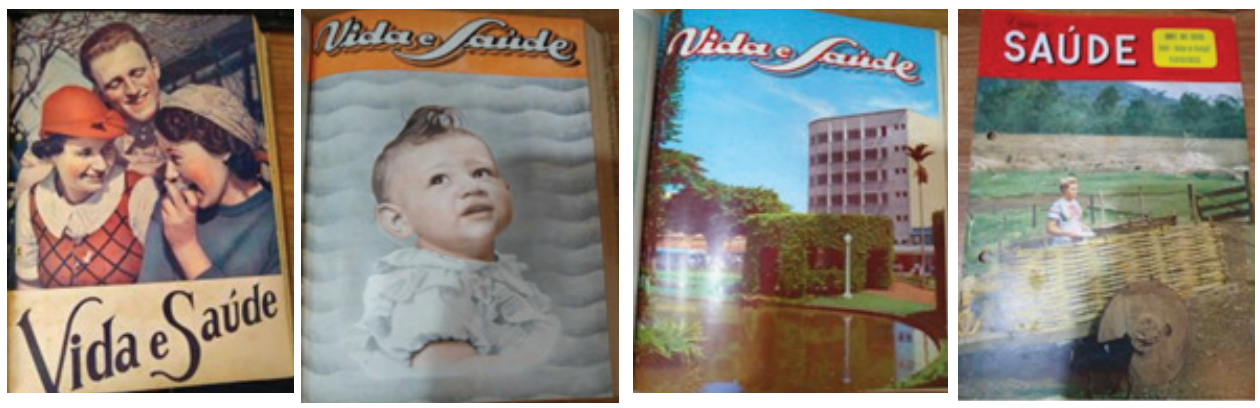

Fonte: Centro White - Unasp-EC.

A segunda capa na fig.1, de abril de 1950, é um exemplo das várias capas com crianças que circularam entre os anos 1930 a 1960 na revista, que traziam fotos de crianças brancas, sem um contexto ou cenário específico, quando muito apareciam em um cenário doméstico, mas como a foto em geral é fechada, isto é, focaliza a criança, não há identificação de onde elas podiam estar. Fotos como a da capa de abril de 1950 mostravam bebês em roupas claras, como símbolo de inocência e pureza - no caso específico desta foto, sua foto foi inserida num fundo do que parecem ser ondas brancas ou seriam nuvens?

A partir dos anos 1970 (fig. 2) a revista conta com um Departamento de Arte que produz suas próprias capas, com uma apresentação mais semelhante ao de outras revistas de consumo popular, como Veja e Visão. As capas têm relação direta com a matéria principal da edição, e trazem chamadas de outras matérias, como podemos ver na figura 2, com a primeira capa, de abril de 1976 sobre a importância de se usar cinto de segurança (que na época não era obrigatório), assim como a luta contra o estresse (segunda capa, de outubro de 1985). Capas sobre alimentação (terceira capa, de dezembro de 2005) e vegetarianismo são recorrentes em todos os anos, e capas sobre maternidade, ainda que menos frequentes, ressaltam o aleitamento materno e a prática de exercícios físicos (quarta capa, de setembro de 2017). Alguns temas que aparecem de maneira recorrente a partir dos anos 1970 seguem também a filosofia do estilo de vida saudável. Desde meados dos anos 2000 
a revista tem apostado em capas com mulheres jovens e magras, em geral brancas, reforçando um ideal de corpo magro, feminino e branco como ideal de saúde. Somente nos últimos anos é que mulheres e homens negros jovens têm ilustrado as capas. Já idosos e homens desacompanhados são menos vistos, assim como temas ligados à religião e à espiritualidade.

Figura 2- da esquerda para a direita - capas de Vida e Saúde de abril de 1976; outubro de 1985; dezembro de 2005 e setembro de 2017 (todas produzidas pela equipe de Arte da revista).
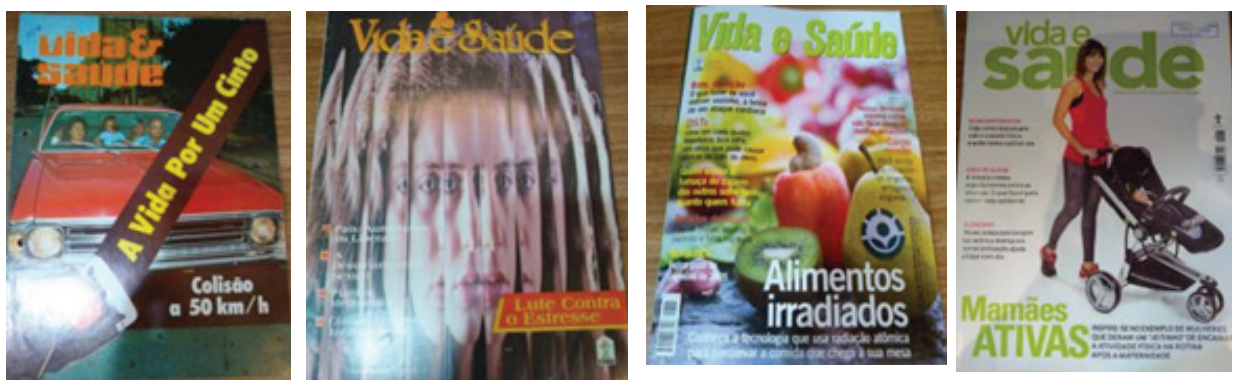

Fonte: Centro White - Unasp-EC.

A maternidade e o aleitamento materno foram mais retratados nas capas a partir dos anos 1970, com fotos de mãe segurando o bebê, em posição de amamentação. Após os anos 1990 é mais difícil encontrar capas que abordem questões de maternidade e puericultura. A novidade nas representações sobre as mães é a capa de setembro de 2017, quarta capa da figura 2, com a chamada "Mamães ativas - inspire-se no exemplo de mulheres que deram um 'jeitinho' de encaixar a atividade física na rotina após a maternidade". A "mamãe" da capa é uma jovem mulher branca, de corpo esguio e em roupas de ginástica, empurrando um carrinho com um bebê dormindo. Trata-se de uma mulher nova e magra, representando o emagrecimento e a boa forma após a maternidade, em meio ao ganho de peso e às mudanças corporais e orgânicas que comumente ocorrem nos corpos das mulheres durante e após a gravidez. Podemos ler a foto como um incentivo ao retorno à antiga forma física antes da gravidez por meio do uso do remédio natural "atividade física", como também um motivo de angústia às mães que estão sobrecarregadas com sua nova atribuição, e ainda se vêm cobradas - ou que se cobram - retomar um corpo anterior à gravidez. A 
chamada também dá a entender que as mães que acabaram de ter seus filhos não seriam ativas - somente as que encaixam exercícios físicos na sua rotina.

Em julho de 2008 foram publicados os resultados de uma pesquisa sobre o perfil dos leitores que a revista fez por meio de correspondência, a partir de um questionário enviado na edição de novembro de 2007 (figura 3). A pesquisa foi feita por livre adesão, e 766 leitores enviaram os formulários respondidos. Os principais resultados foram os seguintes:

Figura 3 - Tabela com Perfil dos/as leitores/as de Vida e Saúde, segundo pesquisa feita em 2007, com 766 respondentes.

\begin{tabular}{|l|l|}
\hline Tempo de assinatura & $\begin{array}{l}61 \% \text { dos leitores são assinantes da revista há mais de } 2 \\
\text { ou } 5 \text { anos }\end{array}$ \\
\hline Compartilhamento & $87 \%$ dividem a leitura da revista com 2 ou mais pessoas \\
\hline Escolaridade & $40,52 \%$ possui o ensino superior completo \\
\hline $\begin{array}{l}\text { Primeiro contato com a } \\
\text { revista }\end{array}$ & $\begin{array}{l}\text { o primeiro contato com a revista foi por meio da visita de } \\
\text { um vendedor (colportor) para } 53,6 \% \text { - seguido da indica- } \\
\text { ção de parente ou amigo }(16,47 \%) \text {, cupom ou propaganda } \\
(9,67 \%) \text { e consultório médico ou biblioteca }(6,67 \%)\end{array}$ \\
\hline Gênero & $73,07 \%$ dos leitores são do sexo feminino \\
\hline Faixa etária & $\begin{array}{l}39,35 \% \text { possui mais de } 50 \text { anos, e cerca de } 36 \% \text { possui } \\
\text { entre } 36 \text { e } 50 \text { anos; o público mais jovem constitui minoria } \\
-26,14 \% \text { (2,61\% com até } 20 \text { anos; } 5,88 \% \text { entre } 21 \text { e } 25 \\
\text { anos e } 17,65 \% \text { possui entre } 26 \text { a } 35 \text { anos). }\end{array}$ \\
\hline
\end{tabular}

Fonte: LEMOS, 2008a, pp. 4-5.

Temos ciência de que se trata de um levantamento feito pela própria revista, num universo limitado e sem um outro tipo de instrumento ou pesquisa feito externamente à editora. Contudo, destacamos algumas informações que surgiram na pesquisam, que fazem refletir sobre os aspectos detectados até o momento: a importância dos colportores e da distribuição pessoa a pessoa da revista; a fidelidade de boa parte do público assinante, que também possui em média alta escolaridade, e divide a leitura com outras pessoas - isto é, os leitores estimados superam a tiragem da revista. Além disso, a maioria dos leitores da revista é composta por mulheres adultas, na meia-idade e na terceira idade. Assim, podemos nos perguntar se essa imagem da saúde nas capas mais recentes da revista promove um ideal de forma física 
e de beleza que não se comunicaria com a realidade de boa parte de seu público-alvo, e com uma parte significativa da população brasileira que está envelhecendo. Segundo o censo demográfico de 2010, a base da pirâmide etária brasileira está se estreitando, devido à queda na fecundidade que vem ocorrendo desde os anos 1960 (CENSO, 2010a). Devemos lembrar que a taxa de fecundidade no Brasil ainda era alta nas primeiras décadas de circulação de Vida e Saúde, o que pode explicar também a maior referência a crianças e bebês em suas capas, enaltecendo a maternidade e a família - se em 1940 a taxa de fecundidade era de cerca de 6,16 filhos por mulher, a partir dos anos 1970 essa taxa cai progressivamente por década, chegando a 1,90 filho por mulher em 2010 (CENSO, 2010b).

No que se refere ao envelhecimento da população, o censo demonstra que o topo da pirâmide etária tem aumentado, devida à queda da taxa de mortalidade, ocorrida de forma significativa desde o levantamento do censo de 1991. Porém, esse envelhecimento de população não aparece nas capas de Vida e Saúde. O envelhecimento é um fato de nosso cotidiano, mas a aceitação da imagem corporal dos velhos ainda é problemática - a juventude ainda é sinônimo de beleza e saúde. Numa sociedade globalizada, exposta às imagens de beldades e celebridades com cinquenta, sessenta ou mais anos conservadas por meio de plásticas e aplicações de botox no rosto, falta encontrar meios de lidar com o envelhecimento e com imagens corporais que sejam plurais. Ainda que a revista Vida e Saúde ofereça conselhos que de fato abrangem diversas medidas de prevenção de doenças, preservação da saúde e qualidade de vida - que resultariam em longevidade - as imagens que ela reserva para se comunicar visualmente ainda a associam a modelos restritos de corpos.

\section{Slogans}

Elencamos na figura 4 alguns slogans pertencentes à amostragem analisada, e que são significativos para demarcar orientações da revista ao longo de sua história. Observamos que de 1939 a 1960 a revista ostenta o slogan "Revista mensal ilustrada sobre saúde e higiene", mudando em 1961 para "Revista mensal em prol de uma vida sã e feliz". A supressão do termo "higiene" acompanha uma tendência mais geral de abandono do discurso higienista no Brasil e em outros países ocidentais. Vertente dominante nas políticas de saúde pública e na academia científica desde o século XIX, o higienismo ofereceu grande suporte para a mensagem de saúde divulgada por Ellen G. White, e foi o grande referencial científico presente tanto nas 
políticas do Estado Novo para educação e saúde, quanto para as matérias divulgadas na Vida e Saúde. Não que a perspectiva higienista desaparecesse por completo de 1960 para 1961 - ela perdura em alguns conselhos até hoje publicados pela revista, mas perdeu força à medida que o Brasil passou por um acelerado processo de urbanização, ampliação (ainda que deficitária) da infraestrutura de saneamento básico e tratamento de esgoto nos anos 1940 e 1950. Além disso, com a ampliação da educação sanitária e de campanhas de vacinação, determinadas medidas sempre veiculadas na revista e em outras publicações da $\mathrm{CPB}$, como o uso correto da água para asseio próprio, e dicas para evitar ambiente de insalubridade na área rural e urbana tornam-se cada vez mais eventuais após os anos 1960.

Figura 4 - Lista dos slogans da revista Vida e Saúde, de 1939 a 2019.

\begin{tabular}{|l|l|}
\hline ANO & SLOGAN \\
\hline $1939-1960$ & "Revista mensal ilustrada sobre saúde e higiene" \\
\hline $1961-1970$ & "Revista mensal em prol de uma vida sã e feliz" \\
\hline $1971-1981 / 2$ & $\begin{array}{l}\text { "Revista mensal de saúde - Revista mensal em prol de uma } \\
\text { vida sã e feliz" }\end{array}$ \\
\hline $1981 / 2-1984$ & "A Revista Mensal da Família" \\
\hline $1997 / 99-2015$ & $\begin{array}{l}\text { Boas ideias para você viver bem (em 2013 o slogan vai para } \\
\text { a capa, logo abaixo do logotipo) }\end{array}$ \\
\hline 2015 até hoje (2019) & Desde 1939 / Boas ideias para você viver bem \\
\hline
\end{tabular}

Fonte: a pesquisadora.

Sai a "higiene" e entra "a vida sã e feliz", que perdura por cerca de vinte anos. Tal slogan coincide com o maior aprofundamento em questões de saúde mental e emocional, com a criação de seções como "Filosofia de Vida", "Um minuto de meditação", "Chaves para felicidade", além de artigos que abordam essas temáticas. Chamamos atenção também para o emprego ainda de uma linguagem formal que durou até meados dos anos 1970 - uma linguagem presente desde o primeiro número da revista, com emprego de "vós", "vossos" - inflexão dos verbos na segunda pessoa do singular e do plural - "Vossas Glândulas e Vossa Disposição" (DONALDSON,1939, pp. 6-7; 22), dentre outros exemplos. Referente à "vida feliz", encontramos artigos e textos de seções que estimulam uma atitude positiva e otimista em 
relação à vida, porém, isso também se encontra eventualmente na revista nas décadas anteriores.

No início da década de 1980, Vida e Saúde passa a ser a "A Revista Mensal da Família", o que não deixa de ser interessante, tendo em vista que no primeiro editorial da revista, "Nosso Programa", o editor Luiz Waldvogel (1939a, p. 3) afirma ser Vida e Saúde uma revista para a família (nuclear e heteronormativa), com artigos para todos - pai/esposo, mãe/esposa e filhos. Nunca abandonou essa perspectiva, ainda que a maior parte de suas publicações se referisse sempre a aspectos da saúde física, independentemente de qualquer membro da família estivesse lendo. Ao assumir, ainda que por poucos anos, o slogan "Revista Mensal da Família", observamos a preocupação em abordar questões de sexualidade, casamento e reprodução, em meio a uma liberação sexual em curso desde o final dos anos 1960 no Brasil - tal enfoque ainda continua em meio à epidemia de aids nos anos 1980, mesmo quando a revista abandona esse slogan por mais de dez anos ${ }^{5}$.

Quando a revista retoma a adoção de slogan, é o que tem sido utilizado até os dias atuais: "Boas ideias para você viver bem". Se antes os slogans sempre eram exibidos na página 2 ou 3 , junto ao índice e ao expediente, a partir de 2013 ele passa a ser exibido logo abaixo do logotipo do título da revista, e desde 2015 tem sido acrescentado "Desde 1939 boas ideias para você viver bem". O tom coloquial do slogan soma-se ao conceito de que a revista sugere - e, não, impõe - boas ideias para o/a leitor viver bem, deixando em aberto o que "viver bem" pode significar. Como a revista aborda de maneira sistemática e articulada desde os anos 1990 a saúde física, mental/emocional e espiritual, o "viver bem" pode abarcar qualquer uma ou todas essas áreas.

\section{Seções}

Apresentamos levantamento sobre as temáticas das seções fixas publicadas na revista Vida e Saúde, de 1939 a 2018, a partir da análise de amostragens anuais de intervalos que vão de cerca de 5, 10 e 15 anos, dependendo da disponibilidade de material para análise. $\mathrm{O}$ intuito foi observar quais as temáticas abordadas, seu grau de frequência nos 80 anos da revista, além de vislumbrarmos as mudanças e as continuidades temáticas entre os

\footnotetext{
5 As questões sexuais nas publicações adventistas foram mais abordadas pela revista Mocidade (1958-1994). Cf. Bach (2020).
} 
dois períodos identificados ${ }^{6}$. A figura 5 traz um gráfico com a síntese destas temáticas, agrupadas em seis categorias: "Saúde física/medicina"; "Saúde mental e emocional"; "Nutrição", "Utilidades domésticas, lar, mulher", "Espiritualidade" e "Infantil".

$\mathrm{Na}$ figura 5, o dado que mais chama atenção é que a saúde física e as novidades da medicina são a temática predominante nas seções. No início da revista, em 1939, havia 4 seções, com cerca de uma página cada "Comentário do Mês" (editorial), "Página da Dona de Casa" (para mulheres), "Novidades Médicas" (saúde física e medicina) e "Para meninos e meninas" (crianças). Atualmente, a revista possui 21 seções - sendo 8 para a saúde física, 4 para saúde mental e emocional, 4 para nutrição, 1 para saúde espiritual, 2 de utilidades domésticas (mais o editorial e as mensagens de leitores, não contabilizados em nenhum dos anos pela sua variedade temática e pela sua intermitência ao longo dos 80 anos).

As seções classificadas como "Saúde física/medicina" abordaram questões relacionadas ao funcionamento dos órgãos e sistemas, educação física, recursos para tratamento e prevenção de doenças, como hidroterapia, plantas/fitoterapia. Agrupamos nesta categoria seções que traziam novidades científicas na medicina, pois elas costumam apontar para descobertas na área da saúde física, como ocorre no caso das seções "Novidades Médicas" (anos 1930-1940; início dos anos 1970), "Notícias Médicas" (anos 1950), "Mosaico Noticioso" (anos 1960 e 1970), "Panorama mundial" (anos 1970 a início dos anos 1990) ou a versão atual dessa seção, "Sala de Espera" (desde meados dos anos 1990). Além disso, listamos as seções de perguntas enviadas por leitores e respondidas por médicos da revista, uma seção longeva que só findou em 2008, com a popularização de internet. Tal seção recebeu diferentes nomes: “O Médico da Família” (anos 1950 a 1980), "Perguntas e Respostas sobre Nutrição e Higiene" (anos 1950), "Conselhos sobre Saúde" (anos 1990), "Vida e Saúde responde" (anos 1990), e por fim, “100 Dúvidas” (2000-2008).

\footnotetext{
6 Coletamos dados em amostragens de intervalos de tempo inicialmente de cinco em cinco anos, a fim de observar mudanças no tempo de seções e artigos. Porém, os números da década de 1960 foram escassos, assim como os da década de 1940. Já os das décadas seguintes foram mais abundantes, e pudemos fazer um levantamento de pelo menos de cinco em cinco anos.
} 
Figura 5 - Gráfico com temáticas das seções fixas publicadas em Vida e Saúde de 1939 a 2018, por número absoluto.

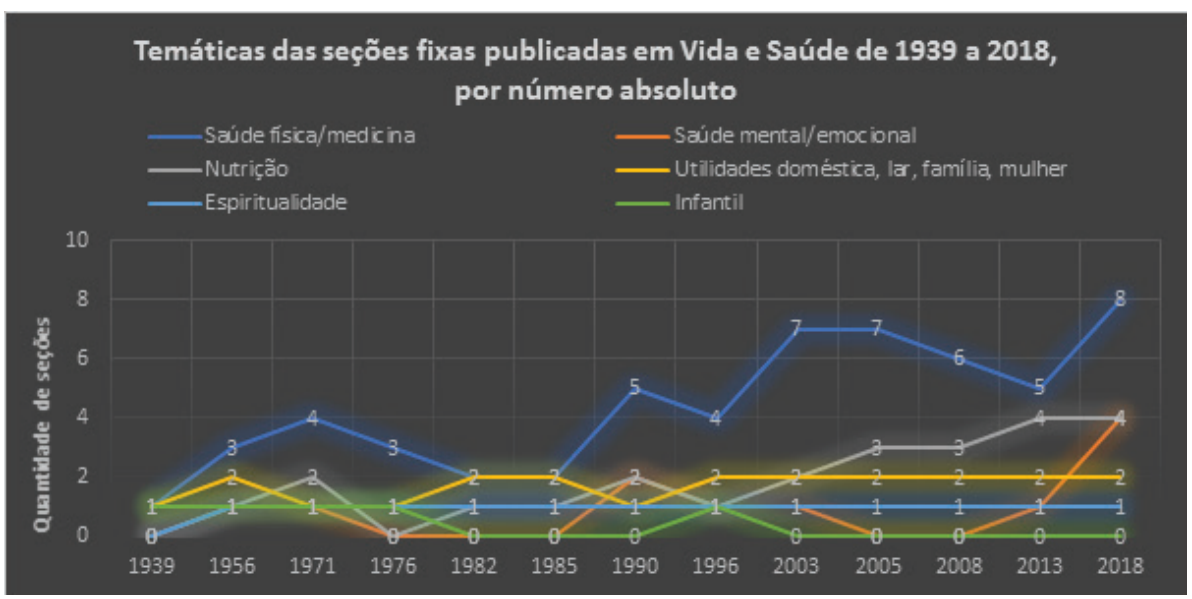

Fonte: a pesquisadora.

As seções de "Saúde mental e emocional" consideraram colunas de psicologia, psiquiatria, sexologia e sexualidade, esta última incluída na categoria de saúde mental nas mais recentes edições da revista, desde 2017. Nas décadas iniciais, havia seções curtas pertencentes a uma seção maior de "Higiene mental", contendo poemas, dicas de jardinagem e por vezes a seção "Filosofia de Vida", que a partir dos anos 1960 trouxe mais temas espirituais, sendo realocada em nossa classificação para a categoria "Espiritualidade". Entre os anos 1930 e 1960, os temas de saúde mental e emocional reforçavam uma atitude positiva em relação à vida e às pessoas da convivência, ou então traziam hobbies que envolvessem a jardinagem - em especial para pessoas que lidavam com atividades intelectuais, de escritório. Assuntos de psicologia, psiquiatria e sexualidade ficaram mais aprofundados a partir dos anos 1970, não tanto em seções, mas em artigos. Alguns autores escreviam com frequência para a revista, mas somente nos anos 2010 tiveram sua seção própria: César V. de Souza, atualmente com a seção Psiquiatria, e Belisário Marques, com a seção Autoestima, desde 1996 publicada, mas era classificada como artigo livre no sumário. Seus conselhos demarcam um discurso clínico científico, que por vezes trazem elementos religiosos na abordagem de problemas emocionais. A presença destas colunas coincide com a crescente atenção popular à saúde emocional e mental na última 
década. Ambos já contribuíram com artigos sobre saúde emocional e sexual em anos anteriores, com uma abordagem clínica e cristã de assuntos como homossexualidade, dentre muitos outros.

A categoria "Espiritualidade" inicialmente é identificada com a seção "Filosofia de Vida", sobre saúde emocional. A partir dos anos 1970 a revista assume permanentemente uma seção sobre espiritualidade, com diferentes nomeações e localizações na revista - ela passou das páginas iniciais para figurar na página final da revista a partir do final dos anos 1990. Segundo Fatima Ali (2009), a última página pode ser escolhida para deixar uma forte impressão no/a leitor/a sobre a filosofia da revista, o que faz compreender a localização da seção de espiritualidade não mais no início e, sim, no final da revista. Ou então, o contrário, pode ser uma estratégia para evitar a rejeição de leitores que não sejam religiosos - e leiam a revista do início ao fim. Não se trata de coluna proselitista nem de identidade adventista, ainda que Ellen G. White seja mais citada nela do que no restante da revista. Na segunda fase da revista, a partir dos anos 1980, ela é escrita por brasileiros adventistas, que trazem uma reflexão espiritual cristã sobre assuntos do cotidiano nacional.

A categoria "Nutrição" agrupou seções dedicadas à alimentação, com receitas, e demonstrações dos aspectos nutricionais, preventivos e funcionais dos alimentos. As seções "Receitas Culinárias" (anos 1950-1960) e "Dietética e cozinha" (anos 1970) dedicaram-se somente à alimentação. Já a seção "Dicas e Receitas”, vigente dos anos 1990 até início dos anos 2000, foi incluída nessa categoria por trazer receitas e aspectos funcionais de alimentos. O mesmo ocorria com seções dedicadas ao lar e à família, dirigido às mulheres, como "Página da Dona de Casa" (anos 1930-1950), "Lar e Cozinha" (anos 1980) e "O Jornal da Mulher" (anos 1980). Contudo, as receitas dividiam espaço com informações de utilidade doméstica, criação de filhos e manutenção da saúde da família, o que nos fez criar a categoria "Utilidades domésticas, lar, mulher", seguindo o discurso voltado para o público feminino, dos anos 1930 ao 2000.

A categoria "Infantil" engloba seções voltadas para as crianças, com histórias morais e passatempos, não chegando a mais de uma página e meia, em média, e foram intermitentes ao longo dos 80 anos. Entre os anos 1930 e 1950, a seção "Para meninos e meninas" trazia histórias morais, de linguagem rebuscada, com textos de autores brasileiros e estrangeiros, e 
não raro continha textos sem autoria identificada ${ }^{7}$. Podemos inferir que a existência da revista Nosso Amiguinho desde 1953, editada até hoje pela Casa Publicadora Brasileira, contribua para o esvaziamento desta seção, mas ainda assim ela reaparece nos anos 1990, em período de crise econômica e baixa tiragem. Desde os anos 2000 ela é inexistente.

Notamos que a saúde física predomina na revista, dirigindo-se a homens e mulheres. As seções para as mulheres sofrem mudanças nos títulos, porém, durante a maior parte do tempo reforçam o lugar das mulheres no espaço doméstico, no cuidado com a família e com o casamento. Isso ocorre tanto na "Página para a Dona de Casa" nos anos 1930 e 1940 (seção semelhante a "The Housewife's Corner", de Life and Health), quanto no "Jornal da Mulher", criado nos anos 1980, com dicas de receitas, cuidado com filhos, com o lar e com a beleza feminina, e antes disso, na seção "Lar e Cozinha".

Vale notar que a seção "Dicas e Receitas" costumava trazer no índice o subtítulo "orientação para o dia-a-dia da mulher" (SUMÁRIO, 2000, p.5), texto que mudou em 2003 para: "informações úteis para casa e cozinha” (SUMÁRIO, 2003 , p.4). Nos últimos vinte anos houve uma diminuição das divisões de gênero para a maioria dos temas abordados nas seções e nos artigos. Desde 2015, culinária não é mais assunto só de mulheres, com a seção "Receitas Vida e Saúde" sendo comandada pelo chef de cozinha Ricardo Fiovarante, com receitas vegetarianas estritas, sem nenhum ingrediente de origem animal. Essa nova fase da seção coincide com a popularidade de chefs de cozinha na mídia, com programas de reality show, como por exemplo, Cake Boss (exibido nos canais a cabo TLC e Discovery Home and Health, em 2015). Pensamos na alimentação como um meio de comunicação (GIUMBELLI; RICKLI; TONIOL, 2019), que estabelece uma fronteira de negociações e acomodações entre adventistas e o público não-adventista. Por exemplo, o maior interesse no veganismo refletiu-se na seção de receitas, agradando tanto aos paladares veganos quanto aos paladares ovolactovegetarianos. Essa é uma mudança sensível, pois até os anos 2000 a revista trazia receitas com ovos e/ou leite e derivados e/ou mel.

Seguindo essa tendência de diminuição do reforço dos papéis de gênero feminino restritos ao lar e à criação dos filhos, houve decréscimo dos conselhos para as mulheres, tornando-se esporádico nos anos mais recentes. A exceção está nos artigos sobre aleitamento materno. Mesmo em maio, o

Vale notar que o título da seção é a tradução da mesma seção na Life and Health, "For boys and girls", porém, os conteúdos de ambas as páginas eram diferentes entre si, mantendo somente a proposta de trazer conselhos de moral e higiene para as crianças. 
"mês das mães", dentro da amostragem analisada, há poucas menções às mães de maneira comemorativa ou mesmo dentro da ótica religiosa - o mesmo ocorre com os pais.

Em suma, na parte das seções fixas, de 1939 a 2018, houve a predominância de temas relacionados à saúde física e aos avanços da medicina, com aumento no número de seções ao longo dos anos, chegando a oito nas edições de 2018 e 2019 ("Sala de espera", "Clínica Geral", "Geriatria", "Odonto", "Plantas", "Beleza saudável”, “Em forma”, "Infográfico"). O número de seções relativas a utilidades domésticas e utilidade pública estabilizou-se, com a ressalva de que as seções que eram dirigidas às mulheres como donas de casa, mães, esposas e cozinheiras perdem essa abordagem, incluindo as seções de receitas. A seção de espiritualidade também se manteve relativamente constante desde os anos 1970, perfazendo ao menos uma seção por mês - atualmente esta é a função da coluna "Vida Plena". As seções de saúde mental e emocional aumentam em número a partir de 1999, com crescimento significativa de 2008 para frente. Desde 2003, as seções de nutrição também crescem (atualmente são quatro), reforçando o compromisso de ensinar a usar o remédio da alimentação corretamente.

\section{Artigos}

À medida que as seções cresceram em número, a quantidade de artigos diminuiu ao longo dos 80 anos da revista. Nunca houve um número fixo de artigos, pois eles dependiam do seu número de páginas. A figura 6 traz gráfico que sintetiza o levantamento de temáticas principais dos artigos das amostragens anuais de Vida e Saúde, com intervalos de cerca de 5, 10 e 15 anos, dependendo da disponibilidade dos materiais consultados. Como utilizamos números absolutos, isto é, a quantidade de artigos publicados por ano, observamos uma queda de todas as categorias a partir dos anos 1970, e mais acentuadamente após os anos 2000. Nos anos 1970 o número de seções é variável, caindo para 4 ou 5 no início dos anos 1980. Os artigos ficam mais longos, o que explica sua queda numérica. Já a queda dos anos 2000, quando a revista atinge 52 páginas, deve-se ao aumento progressivo das seções. Assim, a partir dos anos 2015, a revista tem cerca de 4 a 5 artigos. Classificamos os artigos em cinco grandes categorias: "Saúde física", "Saúde emocional", "Lar, casamento, sexo, filhos", "Nutrição", e “Álcool, fumo, drogas". O critério para classificação baseou-se no tema central abordado pelo artigo, de maneira semelhante ao que classificamos para as seções fixas. 
Durante os 80 anos da revista, a saúde física foi a temática mais destacada também nos artigos, com abordagem secularizada e científica sobre prevenção e tratamento de doenças; funcionamento do organismo e sua fisiologia, alertas quanto a tratamentos nocivos. Algumas doenças figuram com frequência - câncer, obesidade, doenças coronárias e diabetes - todas classificadas como preveníveis, salvo em casos hereditários. Artigos sobre odontologia também estão nessa categoria, antes que eles se tornassem uma seção fixa.

Figura 6 - Gráfico com temáticas dos artigos publicados de 1939 a 2018 em Vida e Saúde.

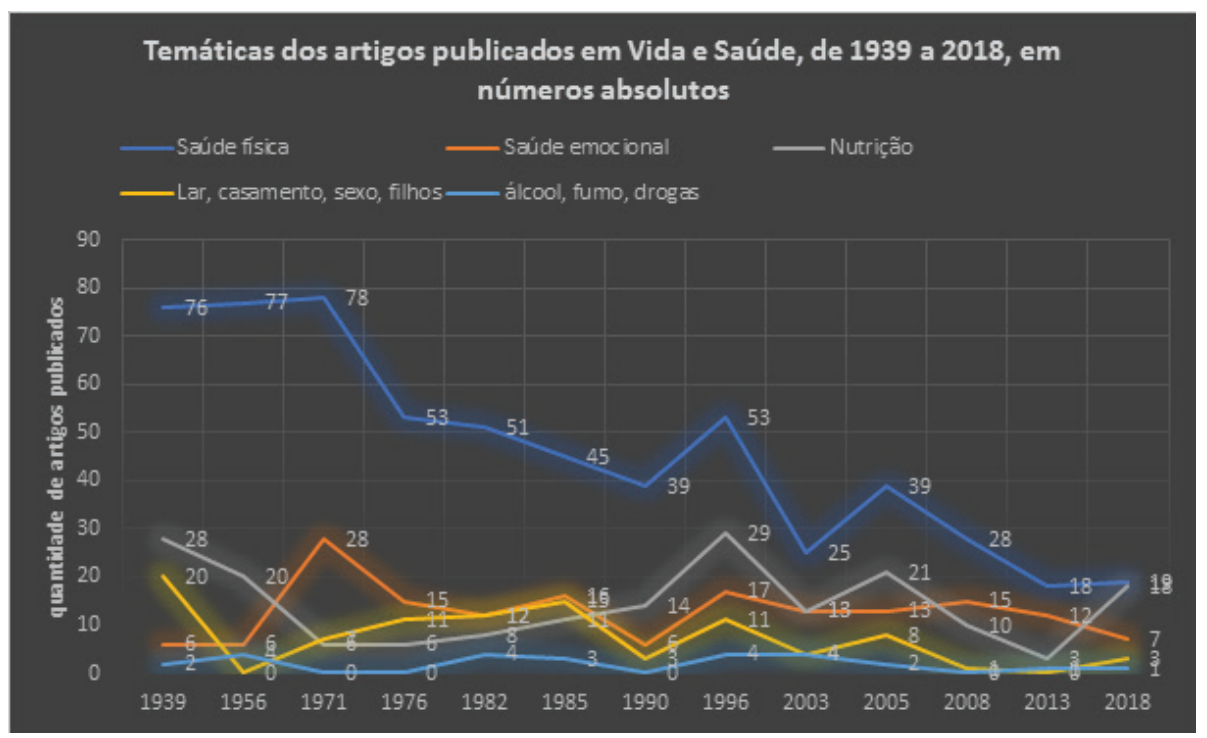

Fonte: a pesquisadora.

A maioria dos artigos tem sido escrita por médicos, e dos anos 1930 a 1970, muitos autores estrangeiros foram publicados ${ }^{8}$. A partir dos anos 1970, aumenta o número de autores brasileiros - profissionais da saúde e jornalistas

8 Identificamos diversas fontes referenciadas pela revista, e outras cujas fontes não foram divulgadas, mas que encontramos nos arquivos digitais de Life and Health. Dentre os veículos que serviram de fonte para Vida e Saúde estavam: Folha da Manhã, que possuía um suplemento de saúde desde 1936; A Gazeta; SNES, SPES-SP; El Centinela (adventista), Viva Cien Años (argentino, científico), dentre outros. Havia também até os anos 1960 matérias não assinadas. 
- e a partir dos anos 2010 é comum encontrar na revista uma lista ao final da matéria com as referências bibliográficas usadas para embasar o texto, em formato de notas de fim. Esse expediente foi utilizado poucas vezes até então, em artigos de médicos americanos. As referências abrangem publicações científicas (livros, periódicos, capítulos de livros), e muitas delas estão disponíveis na internet - tendo seus links devidamente publicados. Trata-se de uma forma de conferir credibilidade científica à revista, demonstrando que as informações traduzidas para o grande público possuem uma origem conhecida e verificável, em um contexto atual de ataques ao saber científico, promovidos em nível global por diversos grupos políticos e sociais.

$\mathrm{Na}$ categoria "Saúde emocional" agrupamos os artigos que lidam com questões de saúde mental e emocional, e por vezes, espiritual (nesse caso, a menção vem em conjunto, pois ela é mais rara de ocorrer em artigos). Matérias sobre depressão, complexo de inferioridade, problemas nos "nervos" foram inseridas nessa categoria. Uma das razões do aumento desta categoria após os anos 1970, mais notadamente de 1996 para frente, é a presença quase mensal dos textos escritos pelo psicólogo Belisário Marques, sobre autoestima. Os conselhos para manter uma atitude positiva em relação à vida e aos relacionamentos mais próximos são substituídos por um questionamento maior dos sentimentos negativos apresentados pelas pessoas, o desconforto em relação a determinados padrões e pressões sociais, os traumas e as decepções que se acumulam e não são trabalhadas pelos indivíduos. Em suma, a saúde mental e emocional é abordada como um aspecto da vida pessoal cujos problemas podem acarretar uma piora na qualidade de vida. Outra tendência recente é a abordagem dos efeitos positivos na saúde com o cultivo da espiritualidade (tomada como sinônimo de espiritualidade cristâ), acompanhando o interesse crescente de parte da medicina nesse assunto (TONIOL, 2017).

$\mathrm{Na}$ categoria "Lar, casamento, sexo, filhos" agrupamos uma série de artigos que, separadamente, contabilizariam muito pouco. Eles englobam temas como: manutenção do lar, vida no casamento, sexo do casal, educação sexual dos filhos, maternidade e criação dos filhos. Nas décadas iniciais, dentro desse rol de assuntos familiares e domésticos, predominaram artigos sobre puerpério - higiene do bebê, aleitamento materno, alimentação do bebê após o período do aleitamento, além dos cuidados com a saúde da gestante. Questões ligadas à sexualidade são raras até os anos 1970, quando a liberação sexual torna-se alvo da imprensa. Os artigos sobre sexualidade 
defendiam que a prática saudável devia ser exercida dentro do casamento, embasando-se em argumentos científicos para justificar a abstinência sexual entre os solteiros. Notamos que até os anos 2000 havia um reforço de papéis tradicionais de gênero, em que recaía sobre as mulheres a responsabilidade de manter a harmonia e a limpeza do lar, a comida saudável para a família, a criação moralmente correta dos filhos e a manutenção do casamento. Contudo, esses assuntos eram mais comuns nas seções fixas.

A categoria "Nutrição" agrupa artigos ligados à alimentação, com ou sem receitas culinárias, que exploram os aspectos nutricionais, funcionais, medicinais de alimentos, além de artigos que versem sobre hábitos alimentares considerados saudáveis pelos editores, quase sempre com alusão ao vegetarianismo. Artigos que relacionam dietas a certas doenças também entram na categoria nutrição, pois ressaltam tanto o caráter deletério de certos hábitos alimentares para causar doenças, quanto a importância dos hábitos alimentares para recuperar a saúde. Uma tendência nos últimos anos na revista é publicar reportagens que vilanizam alimentos processados e refinados, por conterem pouco valor nutricional e muita química prejudicial ao organismo. Nisso a revista reforça o conselho de Ellen G. White de consumir alimentos in natura ou pouco processados, próximos do seu estado natural, para garantir saúde (WHITE, 2013).

Por fim, a categoria "Álcool, fumo e drogas" está separada da categoria "Saúde física" por serem bandeiras de temperança empunhadas pelos adventistas desde suas origens, constituindo o sétimo remédio natural. São artigos que relacionam os efeitos nocivos do consumo de álcool e/ou drogas, além do hábito do fumo para a saúde dos indivíduos e das pessoas de convívio próximo. Nessa categoria, há uma constância de cerca de três a quatro artigos por ano, envolvendo fumo e álcool, porém, desde os anos 2000, com as proibições de propaganda de cigarros e de fumo em locais públicos, houve uma diminuição de artigos sobre esse assunto. As drogas ilícitas aparecem nos anos 1970 e 1980, ligadas à preocupação dos pais em relação aos filhos adolescentes. O álcool é o grande alvo de reportagens que alertam para seus efeitos maléficos, mesmo em quantidades pequenas.

\section{Considerações finais}

O levantamento apresentado neste artigo é o resumo de estudo mais aprofundado feito sobre a revista Vida e Saúde. Trouxemos os aspectos principais da publicação para que sejam ampliados em pesquisas próximas - 
essa primeira aproximação serve para identificar uma uniformidade da filosofia editorial da revista ao longo das décadas. Abordamos a trajetória da revista através do estudo de sua filosofia editorial e sua aplicação efetiva ao longo dos anos em seções e artigos, na comunicação com o público-alvo, na presença de anunciantes e nas suas formas de distribuição, na constituição das capas e dos slogans, e nas possíveis relações entre sua imagética e a interpelação do seu público leitor. Concluímos que há clara distinção entre a constituição da revista, a ponto de estabelecermos uma periodização - uma primeira fase, dos anos 1930 a 1960, mais americanizada, com poucas colaborações de autores brasileiros de sua própria equipe editorial, e uma visão higienista e eugênica da saúde e do corpo; e uma segunda fase, a partir dos anos 1970, em que a revista assume boa parte das matérias e passa a dialogar com temas contemporâneos de saúde brasileira. Ainda podemos pensar que os anos 1970 são a transição de uma fase a outra, pois a partir dos anos 1980 houve uma consolidação deste formato "brasileiro" da revista. Tal classificação, contudo, poderá ser refinada por futuras investigações.

O fato de a revista ter adotado um formato mais estável de seções e artigos a partir dos anos 1970, e posteriormente, nos anos 1980, ter publicado mais textos de brasileiros e reportagens de jornalistas, mostra uma disposição em adotar a linguagem e o formato das revistas de consumo popular da segunda metade do século XX. A predominância de editores jornalistas a partir dos anos 1970 contribui com essa orientação. As capas dialogam mais com o conteúdo da revista, criando chamadas feitas para impressionar leitores/as e futuros/as leitores/as, considerando a distribuição por colportagem. Desta forma, este estudo visou contribuir com uma metodologia de análise para periódicos de maneira geral, tendo em vista a produção de mídia impressa por parte de diversos grupos religiosos no Brasil.

Por sua vez, a revista Vida e Saúde sempre transmitiu a mensagem adventista de saúde, baseada nos oito remédios naturais, ainda que nem sempre o remédio da espiritualidade - confiança em Deus - estivesse presente, assim como a identificação da origem adventista destes conselhos. Dessa maneira, uma questão em aberto a ser explorada são os sentidos do discurso secularizado sobre saúde encampado por grupos religiosos - quais os seus limites e suas razões de existir? A predominância da saúde física, em meio a uma profusão de artigos e seções sobre corpo humano, doenças e conselhos de prevenção, pode ser lida à luz do conjunto que a revista compõe de sua linha editorial e de seu alinhamento às políticas de saúde pública. No primeiro 
período da revista, dos anos 1930 a 1960, prevaleceu a abordagem higienista e eugênica de saúde, seguindo inicialmente as políticas do Estado Novo, além do criacionismo, que concebe o corpo humano como uma criação divina perfeita, que funciona em harmonia quando está saudável.

No período seguinte, após os anos 1970, o higienismo e eugenia dão lugar a uma visão individualista de saúde, em que o sujeito é responsabilizado pela sua saúde e sua doença a partir de suas escolhas de hábitos. Se a revista aproximou-se de temáticas brasileiras, sua ideia de saúde nem sempre considera as disparidades socioeconômicas que impedem muitos cidadãos brasileiros de ter acesso aos oito remédios naturais, como por exemplo, à água tratada e esgoto, a condições para praticar exercícios físicos e manter um repouso adequado, a uma alimentação saudável e balanceada, a condições salubres de trabalho e moradia.

É curiosa a carta da leitora Lílian, que afirmou em 1999 que Vida e Saúde era "um médico em forma de revista", pois o periódico sempre evitou passar tratamentos ou fazer diagnósticos, recomendando somente os oito remédios naturais e corroborando sempre o discurso médico-científico. Ainda assim, se pensarmos em épocas passadas, a revista pode ser compreendida como um meio de instrução e de prevenção num período em que não havia sistema único de saúde. O estudo sobre o periódico também pode ajudar a compreender o corpo como uma instância relevante não somente no adventismo, mas também no cristianismo. Por isso, esta pesquisa também visa contribuir para o crescente campo das investigações sobre religião, saúde e mídia, ao mapear uma fonte produzida por uma denominação que se diferencia de outros grupos brasileiros que atuam na saúde, com práticas de cura divina e serviços mágicos, como parcelas de pentecostais, espíritas e umbandistas.

Os adventistas cultivam uma abordagem secular, racional, que alia fé e ciência no cuidado do corpo - corpo este que, no cristianismo, muitas vezes foi relegado a segundo plano em favor do espírito. Eles retratam o corpo como protagonista na luta contra a gula, a autoindulgência e as tentações da modernidade, para se tornar o templo adequado ao Espírito Santo e provar que os remédios naturais funcionam em qualquer pessoa, e em qualquer tempo.

\section{Referências}

ALI, F. A arte de editar revistas. São Paulo: Companhia Editora Nacional, 2009.

BACH, L. F.C. Sexualidade, beleza e maternidade: o modelo cristão de mulher nos anos 1980 a partir da revista Vida e Saúde. 2017. 64 f. Trabalho de conclusão de curso de 
"Um médico em forma de revista": 517 Aspectos constitutivos da revista adventista Vida e Saúde (1939-2019)

bacharelado em História-Memória e Imagem - Universidade Federal do Paraná, Curitiba-PR. BACH, L.F.C. "Um roteiro seguro e certo, a elevar as almas jovens": Educação afetiva e sexual na revista Mocidade (1958-1994). 2020. 216 f. Dissertação (Mestrado) em História Universidade Federal do Paraná, Curitiba-PR.

BADARACCO, C. H. Prescribing Faith: Medicine, Media, and Religion in American Culture. Waco,TX: Baylor University Press, 2007

BORGES, M. 80 anos da mais antiga revista de saúde do Brasil. Canal Michelson Borges. YouTube. 2019 [?]. Disponível em: https://www.youtube.com/watch?v=TPztOQxngHU. Acesso em 25out2019.

BOrGES, M. A chegada do Adventismo ao Brasil. Tatuí-SP: Casa Publicadora Brasileira, 2000. CENSO DEMOGRÁFICO 2010a. Sinopse. Rio de Janeiro: IBGE, 2012.

CENSO DEMOGRÁFICO 2010b. Nupcialidade, fecundidade e migração - resultados da amostra. Rio de Janeiro: IBGE, 2012.

CORREIO. Revista Vida e Saúde. Tatuí-SP: Casa Publicadora Brasileira, vol. 61, n.1, p.33, janeiro de 1999.

DALBEN, A., \& SOARES, C. L. A revista Vida e Saúde: Modos de olhar e educar o corpo feminino em suas páginas (1940-1950). Pensar a Prática. v.11, n.3, p. 239-250, 2009.

DIWAN, P. Raça Pura: Uma história da eugenia no Brasil e no mundo. $2^{\mathrm{a}}$ ed , São Paulo: Contexto, 2007.

DONALDSON, A. N. Vossas Glândulas e Vossa Disposição. Revista Vida e Saúde. Santo André-SP: Casa Publicadora Brasileira, v.1, n.10, pp. 6-7; 22, outubro 1939.

GIUMBElli, E.; RICKLI, J.; TONIOL, R. (orgs). Como as Coisas Importam: uma Abordagem Material da Religião - Textos de Birgit Meyer. Porto Alegre: Editora UFRGS, 2019.

GRIFFITH, R. M. Born Again Bodies: Flesh and Spirit in American Christianity. University of California Press, 2004.

KOENIG, H. Medicina, Religião e Saúde: o encontro da ciência e da espiritualidade. Tradução: Iuri Abreu. São Paulo: LP\&M, 2012.

LAND, G. Historical Dictionary of Seventh-day Adventists. Lanham, Toronto: The Scarecrow Press, Inc., 2005

LEMOS, A. D. Longevidade saudável na Mídia: entre a medicalização e a promoção da saúde. 2015. 191 f. Dissertação (Mestrado) em Ciências. FIOCRUZ, Rio de Janeiro-RJ.

LEMOS, F. A sua opinião vale saúde. Revista Vida e Saúde. Tatuí-SP: Casa Publicadora Brasileira, ano 70, n.6, p. 4-5, junho 2008a.

LEMOS, F. Os editores. Revista Vida e Saúde. Tatuí-SP: Casa Publicadora Brasileira. Ano 70, n.2, p. 4, fevereiro 2008b. 
LUCA, T. R. História dos, nos e por meio dos periódicos In PINSKY, Carla B.(org). Fontes Históricas. $3^{a}$ ed., São Paulo: Contexto, 2011, pp.111-154.

MARCAS E PLATAFORMAS. Saúde. Publiabril. Disponível em: http://publiabril.abril.com. $\mathrm{br} / \mathrm{marcas} / \mathrm{saude} / \mathrm{plataformas} /$ revista-impressa. Acesso em 25out2019.

NOSSAS AGÊNCIAS. Revista Vida e Saúde. Santo André-SP: Casa Publicadora Brasileira, ano.1, n.1., p. 23, janeiro de 1939a.

NOSSAS AGÊNCIAS. Revista Vida e Saúde. Santo André-SP: Casa Publicadora Brasileira, ano.1, n.4., p. 22, abril de 1939b.

NOSSA CAPA. Revista Vida e Saúde. Santo André-SP: Casa Publicadora Brasileira, v.21, n.5, p. 3, maio 1960.

REVISTA VIDA E SAÚDE. Santo André-SP: Casa Publicadora Brasileira, v.38, n.4, abril 1976.

REVISTA VIDA E SAÚDE. Santo André-SP: Casa Publicadora Brasileira, v.47, n.10, outubro 1985.

REVISTA VIDA E SAÚDE. Santo André-SP: Casa Publicadora Brasileira, v.11, n.4, abril 1950.

REVISTA VIDA E SAÚDE. Santo André-SP: Casa Publicadora Brasileira, v. 1, n.10, outubro 1939.

REVISTA VIDA E SAÚDE. Tatuí-SP: Casa Publicadora Brasileira, ano 79, n.9, setembro 2017.

REVISTA VIDA E SAÚDE. Tatuí-SP: Casa Publicadora Brasileira, ano 67, n.12, dezembro 2005.

ROSSITER, F. A obra prima da Creação. Revista Vida e Saúde. Santo André: Casa Publicadora Brasileira, v. 1, n.2, p. 4-5, fevereiro 1939.

SCALZO, M. Jornalismo de Revista. $2^{a}$ reimpressão. São Paulo: Contexto, 2014.

SCHUNEMANN, H. E. S. Interfaces entre Religião e Ciência no Discurso de Saúde no Adventismo. Anais do Simpósio da ABHR, 2008. Disponível em: http://www.abhr.org. br/wp-content/uploads/2008/12/schunemannn-haller.pdf. Acesso em 02abr2020. Acesso em: 31 mar2020.

SOARES, D. M.; LEOPOLDO E SILVA, L. O.; CAMPOS, P. F. S. Identidade de gênero: a representação da mulher na Revista Vida e Saúde durante a Segunda Guerra Mundial (19401945). Revista Brasileira de História \& Ciências Sociais - RBHCS. Vol. 6, No 11, pp. 142-160, Julho de 2014.

STROPPA, A.; MOREIRA-ALMEIDA, A. Religiosidade e Saúde In SALGADO, M. I. e FREIRE, G. (orgs.). Saúde e Espiritualidade: uma nova visão da medicina. Belo Horizonte: Inede, p. 427-443, 2008.

SUMÁRIO. Revista Vida e Saúde. Tatuí-SP: Casa Publicadora Brasileira, ano 62, n.12, p.5, dezembro 2000.

SUMÁRIO. Revista Vida e Saúde. Tatú́-SP: Casa Publicadora Brasileira, ano 65, n.12, p.14, dezembro 2003.

TONIOL, R. Do espírito na saúde. Oferta e uso de terapias alternativas/complementares nos serviços de saúde pública no Brasil. 2015. 314 f. Tese (Doutorado) - Universidade 
"Um médico em forma de revista": 519 Aspectos constitutivos da revista adventista Vida e Saúde (1939-2019)

Federal do Rio Grande do Sul, Programa de Pós-Graduação em Antropologia Social, Porto Alegre, RS.

TONIOL, R. O que faz a espiritualidade?. Religião e Sociedade, Rio de Janeiro, 37(2), p. 144-175, 2017.

WAldVOGEL, L. Nosso programa. Revista Vida e Saúde. Santo André: Casa Publicadora Brasileira, v. 1, n.1, p. 3, janeiro $1939^{\mathrm{a}}$.

WAldvogel, L. O Comentário do Mês. Revista Vida e Saúde. Santo André: Casa Publicadora Brasileira, v. 1, n.12, p. 3, dezembro 1939b.

WHITE, E.G. A Ciência do Bom Viver. Ellen G. White Estate, Inc. E-book, 2013 [1905].

Submetido em: 7-4-2020

Aceito em: 15-8-2020 